\section{ROYAL COLLEGE OF PHYSICIANS OF} LONDON

At a quarterly meeting of the College held on 29 January, with the president, Sir Max Rosenheim, in the chair, Colonel R. G. MacFarlane was appointed to the chair of military medicine held jointly between the College and the Army Medical Service.

The following were appointed or reappointed College representatives :

Dr. E. G. G. Rhind (Sheffield Regional Postgraduate Committee), Dr. R. Mowbray (Medical Postgraduate Committee of the University of Newcastle), Dr. W. D. Brinton (Wessex Postgraduate Medical Committee), Dr. G. S. C. Sowry (North-west Metropolitan Region Postgraduate Committee). Dr. A. W. Woods (South-west Metropolitan Region Postgraduate Medical Committee), Dr. H. Kopelman (Northeast Metropolitan Region Postgraduate Medical Committee), Dr. J. S. Staffurth (South-east Metropolitan Region Postgraduate Medical Committee), Dr. F. J. W. Miller (Central Midwives Board)

Dr. A. N. Exton-Smith was elected to the Council in place of Dr. J. C. Gilson who had resigned.

The following, having satisfied the Censors' Board, were admitted Members of the College :

Rosemary P. Biggs, G. F. Hall, J. R. O’Brien, J. L. Turk.

Licences to practise were conferred upon the following candidates

M. S. A. Ahmed, D. N. Anderson, D. H. Austwick, R. C. L. Au-Yong, D. A. Baker, A. A. Bell, Barbara S. Best, Margaret A. Bielenky, M. D. Boll, Bowen, N. M. Breach, D. S. Briggs, Shelagh L. Calvert, R. D. G. Carmichael, P. S. Cary, A. J Shwing C. Chen, H. W. Chilton. J. M. F. Clarke G. S. Clayden, A. R. Close, A. S. Coulson, Carme A. E. Coulter, Anne V. N. Cream, D. J. Cubitt, D. A. Curson, Suzanne Daddy, Jyotirmoy Datta Dendy, M. B. Denton, M. E. Denyer, N. J. Dodd Susan F. O. Dowling, C. G. Dowman, Josephine M. Drake, D. R. Elliott. P. J. D. Evans. M. H. Faulkner, Charlotte N. Gardiner, A. L. Gent. C. M. R. Glaysher, Yvonne F. S. Glen, J. D. S. Goodman J. A. A. Govan, D. K. Grieve, M. Hali. Susan M. Harrison, Hilary M. Hart. R. B. Hartley, R. D. Hartley, M. J. Hawkins, P. J. M. Hartey, R. M. Henry, M. R. Hetzel, G. B. Hey, D. J. Hill, Carole D. Hopkins, M. Horrocks, K. M. Howard. Hilary C. Hubbard, A. Hutchinson, I. T. A. Jeffery, A. C John, D. A. Jones, I. V. Jones, Linda C. Jones, M. A. Jones, Dorothy V. Joss, S. C. Kahwati, M. A
Kassimi, P. J. Kaye, M. A. Knight. J. W. S Kraemer, A. J. Lamerton, F. D. J. Lane, J. A. Lomax. Cornelia A. McCarthy, I. D. McHardy, I. N. McIntyre, Jane E. Mackay, R. A. McKenzie, Massoud. Sandra D. Mather, N. E. D. Mattison. M. H. Meanley, M. C. Moore Ede, I. J. Morgan D. N. Morton, R. W. Motson. A. J. Mourant, R. W Neale, E. Neville, J. H. Newman, Jane G. B. Newson-Smith, C. F. Ngui, M. J. Noaks, F. O. Nwator, E. O. Oji, M. P. Osborne. Beatrice M Ounsted, K. Pearman, B. J. Penney, D. B. Penwarden, J. H. Pitt-Payne, Josephine G. Plummer G. Rees, D. F. A. Richards, Mary E. Rodoman, G. T. Royle, Hanna F. Sayegh, D. V. Seal. M. F Shiu, W. H. Smith, K. J. B. Sommi, D. J. Soalton, Deborah J. Stephenson, M. K. Tan. M. A Trevitt. R. G. Turner, J. W. Treasure. Heather M. Wass, J. M. Wakely, R. K. Walesby, Angela $M$ Walker, A. R. Waygood, P. D. Welsby, M. I. Whitehead, Frances E. Whiting, H. J. H. Williams, Woodhouse, R. L. Woods, M. E. Worby, G. I Zychova.

Diplomas were granted, jointly with the Royal College of Surgeons of England, as follows :

Diploma In ANaksthrtics.-A. J. Adeney, A. K Ali, H. S. Ali, D. K. M. Allison, Rosalind M Andersen, B. D. Apthorp, Sudha Arora, A. S
Banks, P. M. Bashir, A. M. Bateman, G. T. Bell,
Rosemary J. Berry, P. B. Bhangdia, F. lognini, M. Bose Babu, R. F. Boucher, Christine M Brookes, G. D. Brown, B. H. Bullas, S. K. Bushra F. H. A. Cader, C. R. D. Campbell, G. L. M Chittaranjan Babu, A. R. Clifford, Pamela J. Coats,
D. F. Cochrane, D. I. Cooper, Margaret Cropper,
B. H. Dalal, Margaret C. Davison, Dipa De, H. P.
Didier, J. T. Doneley, I. A. R. Dunnett, A. J. N. French, W. A. Frodsham, R. C. Gilbertson, Tilina M. Gunasekara, Laila-Abd El-Rahman Hamed, M. Mahfooz-UI Haque, v. V. Hardikar, Julia C. Harper, M. Hashim, N. J. Healey, N. A. Hodges, Margaret E. Hodson, J. E. Holiday, W. J. M. Hynd, Patricia M. Irving, M. H. Islam, N. R Jackson, J. P. H. Jago, Luckshmi Leela-de-Silva Jayasekara, Sumangala S. Kadam, Santosh B. Kalhan, J. W. L. Kemp, I. Kennedy, A. H. Khan, vinder K. Kukreja, R. A. Leathem, Maddineni Macpherson, Elizabeth G. Maddison, R. F. J. Macpherson, Elizabeth G. Maddison, R. F. J. Moudgil, J. M. Moy-Thomas, Valerie M. J. Muir, V. W. Nimbkar, P. M. Norton, P. Notananda, K. Simarani Pai, Joan L. Pallett, Kalpana K. Parikh, Jane E. Parry, Niranjana P. Patel, Billie R. J. Porter, Suzanne E. Powrie, K. N. Rao, M. G. Ridley, H. A. M. Roake, A. J. Robertson, J. R. Saravanabavananthan, Rupali Sarkar, Sibani Sarkar, Jaya H. Shah, M. S. Y. Shariff, O. N. Sharma, F. J. Shaw, R. E. Shaw, Rupa N. Shetty, Rosemary A. Sibert, M. O. Siddiqui, Patricia M. Skilling, J. J.
Sneddon, Janet A. Sneddon, Evelyn D. Spark, R. Sneddon, Janet A. Sneddon, Evelyn D. Spark, R. Srinivasalu Naidu, K. Sudhir, Md. Tajuddin, S. Thakuria, W. O. H. Thomas, R. W. Ware, C. J Watkins, M. Wazih Ullah, T. B. Webb, Susan J. Margaret M. Williams, G. A. Wilson,
Florence F. Y. Yoong, W. A. C. Young.

Diploma in Chind Health.-L. B. H. Boxall, L. Piliso.

Diploma IN InDUSTrial Hralth.-B. Dansie

Diploma In Medical Radio-Dingnosis.-P. R Bradley-Moore, Merennage P. N. Fernando.

Diploma In Medical Radiotherapy.-E. KimYou Chow, S. Ganesan, Vera Kraus-Urbach, A. W Lees. M. J. Moriarty, V. Muscat, J. S. Niblett, Rastogi, E. Raubitschek, A. Routh, A. W. Saikali, Svoboda.

DIPLOMA IN LARYNGOLOGY AND OTOT OGY.-J. M. Adams, K. Ahmad, A. K. Chaudri, S. S. Deshpande, S. A. Guindi, P. A. Hood, A. A. O. Mistry, S. N. Mody, D. A. Patel. A. C. P. Raja-

Diploma In Ophthalmology.-R. H. J. Darvell. Dipioma in Pathotogy.-M. A. Aboderin. A. A. Bruce-Tagoe, J. L. Dunscombe, E. M. O. Elamin.
Janis M. Hawkins, E. Kagan, S. E. Lim, I. M. Diptoma IN PsYchor ogtcal MEDICINE - M Ahmar, E. R. Alexander, E. K. Arfai. M. O. Ave Bardhan, J. E. B. Bedford-Turner, R. J. Belas. M. K. Bhakta, Anthea Blofeld, A. J. Broar heat, W. C. Canning, Joan Chappell, G. Clayton, C. G. Conway, A. A. El-Gaaly, J. A. Flowerdew, A R. Eaton, R. M. Galloway, A. B. Gardiner. Patricia A. J. ath. J. G. Hebditch, Judith M. Heron, I. E. Hoult, Lesley K. V. Howell, B. G. Humblestona. T.. H, Im, Zdeněk Janda, G. K. Kapoor, Kandiah KathBeryl C. E. Langley. T. Lawlor. M. A. R. Lee, S.
S. Maan, R. D. McFarlane, S. A. Mahmud. M. T. Salcolm, B. Malekpour, N. S. Marks. M. Masond
Man, M. M. Mand J. Milne, D. B. Minton. v. H. Morcos. M. M Naraghi, Ursula V. P. Naylor, N. Neophytou, R Palmer, R. J. A. Orkins. D. C. R. Pitcher. S. A Qadeer, $\mathbf{M}$. J. Raschid, L. Gnana-Ananthan Ratnasabapathy, I. Ray, K. Raychaudhuri. P. J. M. M. Rostron, El-Sayed M. Saad, Mary H. Sandall, P. C. G. Smith, S. M. Smith. A. G. Stevens, K Sundararajan, M. S. Abdel-Rahman Taman, J. S. Tsiantis, P. J. Tyrer, S. P. Usha, $w$. Waheed, R

Diploma nn PUblic Health.-J. K. Y. A boagyeAtta, J. K. Anand, H. Aramy, K. Dariapeyma, G. R. M. Fernando, Marie J. Freeman, B. H. Gooch, Evelyn E. Hodgson, Rosemary Koinange, Jumroo Mikhanorn, Lysbeth R. Vaughan Jones.

Diploma in Tropical Medicine and Hygizne.-

ROYAL COLLEGE OF PATHOLOGISTS

The following have been admitted to the Membership :

D. J. Allan, M. C. Anderson, I. D. Ansell, W. A Black, Jean Brown, J. Burns, C. H. Cameron,

\section{Sublime and Inventive Genius}

\section{Notice to Authors}

Drysdale, W. N. Eastham, C. W. Edwards, G. H. Marguerite P. Holley, A. W. Jones, C. T. Keane, Orrell, Ranee Nimal Perera, M. A. Prenton, $\mathbf{S}$. ao, Joan D. Rivett, R. Sibbald, H. Singh, Pushpa Sitlani, D. Spencer, S. G. Subbuswamy, Elizabeth J.
Thomson, J. H. Williams, M. P. Walsh.

\section{Deaths}

De.-On 3 January, 1970, Gopeswar De, M.B., Ashington, Northumberland, aged 40.

M.R.C.S., L.R.C.P., of 135 Torrington Park, London, N.12, aged 55 .

\section{Correction}

In the review by Professor W. H. McMenemey (24 January, p. 220) of the book fohn Hunter essie Dobson, the cart conveying garden town should have been described as being drawn by zebus.

\section{Vagotomy for Peptic Ulceration}

Mr. Harold Burge points out that he should have given 2-4 mm. of water as the rise in gastric pressure indicative of incomplete vagotomy in his letter of 31 January (p. 301).

When original articles and letters for publication are not submitted exclusively to the British Medical fournal this must be stated.

Correspondence on editorial business should be addressed to the Editor, British Medical fournal, B.M.A. House, Tavistock Square, London W.C.1. Telephone: 01-387 4499. Telegrams: Aitiology, London W.C.1.

Authors wanting reprints of their articles should notify the Publishing Manager, B.M.A House, Tavistock Square, W.C.1, on receipt of proofs.

\section{Subscriptions}

Members' subscriptions should be sent to the Secretary of the British Medical Association B.M.A. House, London, or to the Scottish Secretary, B.M.A. Scottish Office, Drumsheugh Gardens, Edinburgh.

Doctors who are not members of the B.M.A can subscribe to the B.M.F. The rates for doctors resident in the United Kingdom and abroad are given on the first page of the classified advertisements. These include the rate for the North American "Air Express," which is available to both members and non-members of the B.M.A.

\section{Classified Advertisements}

Doctors Abroad.-Copies of the appointment vacancies advertised in the B.M.f. can be sem by airmail on request. Members' rate: the minimum cost is 40 s. for six weeks' supply, for which copies of vacancies in up to five sections of the classified advertisements will be sent. Non-members' rate $60 \mathrm{~s}$. minimum for six weeks' supply of five headings or less. Additional headings (for members and nonmembers) 10s. each for six weeks' supply. Orders for specific grades in any section cannot be accepted. Payment must be prepaid and enclosed with the application.

Details of rates, etc., for classified advertisements appear on the first page of the classified section. 